\title{
SOCIO-DEMOGRAPHIC AND CLINICAL PROFILE OF CHILDREN WITH ASTHMA ATTENDING CHEST CLINIC AT B. P. KOIRALA INSTITUTE OF HEALTH SCIENCES, NEPAL
}

\author{
Satish Yadav ${ }^{1 *}$
}

\begin{abstract}
Affiliation
1. Associate Professor, Department of Pediatrics, Birat Medical College and Teaching Hospital (Current), Nepal
\end{abstract}

\section{ARTICLE INFO}

Received : 02 May, 2020
Accepted : 05 August, 2021
Published : 04 November, 2021

(c) Authors retain copyright and grant the journal right of first publication with the work simultaneously licensed under Creative Commons Attribution License CC - BY 4.0 that allows others to share the work with an acknowledgment of the work's authorship and initial publication in this journal.

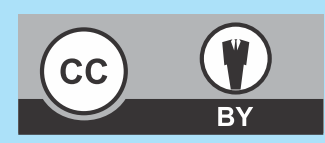

ORA 244

DOI: https://doi.org/10.3126/bjhs.v6i2.40304

\section{* Corresponding Author}

Dr. Satish Yadav

Associate Professor

Department of Pediatrics

Birat Medical College and Teaching Hospital (Current), Nepal Email: doctorsat_99@hotmail.com ORCID: https://orcid.org/0000-0002-3650-5276

\section{Citation}

Satish Yadav. Socio-demographic and Clinical Profile of Children with Asthma attending Chest Clinic at B. P. Koirala Institute of Health Sciences, Nepal. BJHS 2020;6(2)15. 1426-1431.

\section{ABSTRACT}

\section{Introduction}

Asthma in children is one of the most common chronic diseases and little information available on factors associated with this disease in our part of the world.

\section{Objective}

The present study is an attempt to find out the sociodemographic and clinical profile of children with asthma.

\section{Methodology}

This was a retrospective analysis of data of asthmatic children below 14 years attending pediatric chest clinic from July 2014 till March 2016.

\section{Results}

Of the 200 children, there were 142 (71\%) males. The median age of presentation was 3 years and 139 (69.5\%) from the age group 1-5years One third had poorly controlled asthma. Comorbidity was present in 59(29.5\%) and allergic rhinitis (7\%) was the most common. $90.5 \%$ had onset of wheezing before 5 years of age. Family history of asthma and/or atopy and smoking was present in $24 \%$ and $31 \%$, respectively. $22 \%$ had exposure to pet animals. Upper respiratory tract infection (URTI) (37\%) was the most common trigger for exacerbation. Cough (99\%) and fast breathing (98\%) were the most common symptoms.

\section{Conclusion}

The majorities were males of young age with rhinitis as most common co-morbidity and many of them had a history of parental smoking at home. One third of them had poorly controlled asthma which shows the need for proper management of asthma including its comorbidity in younger children and changing certain habits like parental smoking at home.

\section{KEY WORDS}

Asthma, Level of Asthma Control, Children 


\section{INTRODUCTION}

Asthma is one of the most common chronic diseases in the world. The prevalence of asthma has been reported from different parts of the world, with figures ranging from $1 \%$ to $20 \%$ for both children and adults. It is estimated that around 300 million people in the world currently have asthma with 250,000 annual deaths attributed to the disease. Almost all of these deaths are avoidable. The International Study on Asthma and Allergies in Childhood (ISAAC) showed a significant worldwide variation in the prevalence of symptoms of asthma, with the highest prevalence in English speaking Western countries and the lowest prevalence in Eastern Europe and Asia. Most asthma-related deaths occur in low and lower-middle income countries. There are limited reports regarding prevalence of asthma in children from Nepal. The report from neighboring country India shows wide variation (4-19\%) in the prevalence of asthma in school going children from different geographic areas. There is evidence that over the last 20 years its prevalence has considerably increased, especially among children.

Many children with asthma are under-diagnosed and undertreated in our region which may be due to lack of proper treatment and follow up with a knowledge gap among the caretaker and pediatrician. In addition, there are various environmental and genetic risk factors which are different from one region to another. Hence, we need to identify regional socio-demographic and clinical profiles in order to have efficient prevention of acute asthma and its management. Therefore, the aim of this study is to find out the socio-demographic, clinical profile and various factors associated with asthma exacerbation in children.

\section{METHODOLOGY}

This was a retrospective study which was carried out at the Department of Pediatric and Adolescent Medicine of B. P. Koirala Institute of Health Sciences (B.P.K.I.H.S) between July 2014 and March 2016. It is a tertiary center in eastern region of Nepal which has a well equipped Pediatric department. The study population included all the patients of age group 1 to 14 years with asthma attending the pediatric chest clinic in this institute. The diagnosis and level of control of asthma were established using the Global Strategy for Asthma Management and Prevention, Global Initiative for Asthma (GINA-2014). The diagnosis of asthma is defined by the history of respiratory symptoms such as recurrent wheeze, shortness of breath, chest tightness, and cough that vary over time and in intensity. Level of control was divided into: well controlled, partial controlled, or uncontrolled. Tables 1 summarize the levels of asthma control. The children who have congenital heart disease, tuberculosis, anatomical anomalies and other diseases with involvement of respiratory systems were excluded from the study. The diagnosis was made on the basis of detailed history and clinical examination of each patient. Information was collected concerning details of demographic profile including detailed history, age of first episode of wheeze, exposure of smoke and pet animals, family history of asthma and atopy and factors responsible for exacerbation were evaluated in the outpatient department. Level of control was divided into: full control, partial control, or uncontrolled. The data regarding the variables was collected through a pre semi-structured questionnaire. The present study was approved by the Research Ethics Committee at BPKIHS.

All data were collected in a pre designed data sheet and analysis was done using the Statistical Program for Social Sciences (SPSS) 11.5 version. The statistical analysis was done by proportions and percentages.

Table 1 - Levels of control of asthmatic patients.
\begin{tabular}{|l|c|c|l|}
\hline Level of asthma symptom control \\
\cline { 1 - 1 } In the past 4 weeks, has the patient had: & $\begin{array}{c}\text { Well } \\
\text { controlled }\end{array}$ & $\begin{array}{c}\text { Partially } \\
\text { controlled }\end{array}$ & Uncontrolled \\
\hline Daytime symptoms more than twice/week & \multirow{2}{*}{$\begin{array}{c}\text { None of } \\
\text { these }\end{array}$} & $\begin{array}{c}1 \text { or } 2 \text { of } \\
\text { these }\end{array}$ & $\begin{array}{c}3 \text { or } 4 \text { of } \\
\text { these }\end{array}$ \\
\cline { 1 - 1 } Any night waking due to asthma? & Reliever needed more than twice/week? & & \\
\cline { 1 - 1 } Any activity limitation due to asthma? & &
\end{tabular}

\section{RESULTS}

The study included 200 cases; of them 143(71.5\%) were diagnosed at the institute. There were $142(71.0 \%)$ males and $124(62 \%)$ from urban areas. 62 (31\%) were passive smokers. 139 (69.5\%) cases of bronchial asthma were of age group 1-5 years [median age 3 (2-8.5)] [Table 3]. Among associated conditions, rhinitis was the most common 28 (14\%), followed by eczema $14(7 \%)$ and urticaria $8(4 \%)$. Ninety percent of children experienced their first episode of wheeze before 5 years of age. 44 (22\%) have exposure to pet animals. Family history of asthma and or rhinitis was present in 48 (24\%) cases. Among cases diagnosed at our center, 126 (63.0) had controlled asthma. [Table 4]. There were a total 84 numbers of exacerbations during the study period and URTI 31 (37\%) was the most common trigger followed by cold weather and treatment defaulter [Table 5]. Among respiratory symptoms, cough was the most common symptom (99\%), followed by fast breathing (98\%), noisy breathing (81\%) and breathlessness (76\%).

Table 2: Demographic Profile of children of bronchial asthma

\begin{tabular}{|l|c|l|}
\hline & Demographic Profile & Number (\%) \\
\hline Gender & Male & $142(71.0 \%)$ \\
\hline Residence & Female & $58(29.0 \%)$ \\
\hline & Urban & $124(62 \%)$ \\
\hline Passive Smoking & Rural & $76(38 \%)$ \\
\hline & Yes & $62(31 \%)$ \\
\hline Diagnostic status & No & $138(69 \%)$ \\
\hline & Newly diagnosed & $143(71.5 \%)$ \\
\hline
\end{tabular}


Table 3: Age distribution of children with bronchial asthma.

\begin{tabular}{|c|c|}
\hline Age Group & Number (\%) \\
\hline $1-5$ years & $139(69.5 \%)$ \\
\hline $5-10$ years & $42(21 \%)$ \\
\hline$>10$ years & $19(9.5 \%)$ \\
\hline Total & 200 \\
\hline
\end{tabular}

Table 4: Distribution of patients according to level of control

\begin{tabular}{|l|l|}
\hline Level of Control & N (\%) \\
\hline Controlled & $126(63.0)$ \\
\hline Partial control & $68(34.0)$ \\
\hline Uncontrolled & $6(3.0)$ \\
\hline Total & 200 \\
\hline
\end{tabular}

Table 5: Distribution according to triggers responsible for exacerbation

\begin{tabular}{|l|l|l|}
\hline $\begin{array}{l}\text { S. } \\
\text {. }\end{array}$ & Trigger & N (\%) \\
\hline 1 & $\begin{array}{l}\text { Viral/ Upper Respiratory Tract } \\
\text { Infection (URTI) }\end{array}$ & $31(37.0)$ \\
\hline 2 & Weather (cold/ change/rain) & $15(17.8)$ \\
\hline 3 & Defaulter & $8(9.5)$ \\
\hline 4 & Food/drug & $7(8.3)$ \\
\hline 5 & Step down & $6(7.1)$ \\
\hline 6 & Dust & $6(7.1)$ \\
\hline 7 & Smoke & $5(6.0)$ \\
\hline 8 & Passive smoking & $4(4.7)$ \\
\hline 9 & Exercise & $2(2.3)$ \\
\hline & Total & 84 \\
\hline
\end{tabular}

\section{DISCUSSION}

In the present study, the prevalence in males was found higher than females which was also reported by other studies. ${ }^{8-10}$ T seet al. explained that male sex is a risk factor for wheeze in children. As children get older, the difference narrows and by adulthood the prevalence of asthma is greater in women than in men. The reasons for these sex- related differences are not clear. In contrast, a study by Ali et al. ${ }^{12}$ in Egypt stated that, there was no significant difference in the prevalence of asthma among male and female patients below 15 years of age.

In this study more than $90 \%$ of the children had their first episode of wheeze before 5 years of age. These results are consistent with the study conducted by DSY Lam et al and concluded that more than $90 \%$ of the children had their onset of asthma symptoms before 6 years of age. ${ }^{13}$ Wheezing is most often related to viral infections of the respiratory tract in the first year of life. Respiratory syncytial virus is the most important agent, affecting up to $70 \%$ of children in the first year of life. ${ }^{14}$ Some studies have shown that hospitalizations for bronchiolitis is an independent risk factor for developing asthma. ${ }^{15,16}$

Urban-specific lifestyle and environmental factors modify immune development in early life, and the subsequent risk of asthma. ${ }^{17}$ Urban dwelling children were more likely to develop asthma compared with rural children in our results, which is similar in other studies. ${ }^{18,19}$

Among previously diagnosed asthma cases $37 \%$ had inadequate control of symptoms showing poor awareness of asthma management, as supported by others. ${ }^{20-24}$ Several factors may be involved in asthma control. Adherence to treatment, identification and treatment of co-morbidities and triggering factors, availability of medications, and education of patients and their families may play a fundamental role in this goal. ${ }^{25,26}$

Asthma is a disease that may be related to other atopic disorders. Allergic rhinitis is the disease most often associated with asthma. Some authors consider the two diseases as a single inflammatory process of the airway, sharing the same pathophysiology, triggering factors, and environmental risk factors. ${ }^{27-28}$ In the present study, rhinitis was associated with asthma in $14 \%$ of patients. The control of symptoms of rhinitis in asthmatic patients is essential, as this combination may lead to an increased need for medication to control asthma, worsening the quality of lives of patients and increasing costs and demand for health care services. $^{29}$

In our study, 48 (24\%) patients were having family history of asthma which is inconsistent with the findings of Wylie Burke et al who stated that a family history of asthma was a significant predictor of physician diagnosed asthma in children regardless of race/ethnicity and socioeconomic status. Findings support the collection of family history, including grandparent asthma status. Similarly, Mahdi B et al stated that family history of asthma is important determinants in the development of asthma in the offspring. ${ }^{30-31}$

Out of 200 patients $62(31 \%)$ patients were having a history of parental smoking at home and this finding is slightly more as compared to other studies. ${ }^{32,33}$ Study has shown that interactions between genotypes at specific loci or genome regions and environmental tobacco smoke exposure with risk for the development of asthma. ${ }^{34}$

In the present study $22 \%$ of children with asthma have animals at home. A study by Vanessa Mika et al reported $49.4 \%$ children. ${ }^{35}$ Hesselmar et al. and Hölscher et al. have observed that pet exposure during the first year of life or 
currently is inversely associated with childhood asthma. ${ }^{36,37}$ Linneberg et al. found that previous or continuing exposure to a cat at home increased the risk of developing a sensitization to cat in adulthood, while having a dog at home did not increase the risk of developing a sensitization to dog. ${ }^{38}$ Similarly, Oberle et al. observed a significant association between continuous exposure to cats from early life on and asthma in childhood, whereas exposure to dogs was not related to the prevalence of asthma. ${ }^{39}$

URTI was the most common trigger for asthma exacerbation in our study. Viral respiratory tract infections are frequent and usually self-limited illnesses. For patients at risk for asthma, or with existing asthma, viral respiratory tract infections can have a profound effect on the expression of disease or loss of control. ${ }^{40}$ In a study of children aged 9-11 years, $80-85 \%$ of asthma exacerbations that resulted in reduced peak expiratory flow and wheezing were due to viral upper respiratory infections. Various other studies also found that viral respiratory infections are associated with asthma exacerbations in nearly $80 \%$ of these episodes.,

\section{CONCLUSION}

Very few studies have been conducted in Nepal on pediatric asthma. We found that bronchial asthma is a disease of young age from urban areas with rhinitis as most commonly associated co-morbidity. The most common trigger for asthma exacerbation was URTI and onset of the first episode of wheezing before five years of age. Despite some limitations, this study shows that one third of them have poorly controlled asthma which is very high and can be utilized for the improvement of health care measures for its control in our region.

\section{ACKNOWLEDGEMENTS}

My sincere thanks to the department of pediatrics (BPKIHS) for their effort in data collection and entry of the medical records. I would also like to thank to Dharni Dhar Baral for his help in data analysis.

\section{RECOMMENDATION}

We recommend to conduct more research to clearly define the prevalence, sociodemographic profile and factors associated with uncontrolled asthma in our region. We also recommend finding out the causes of such a large proportion of uncontrolled asthma in small children so that the government can develop the policies and programs for pediatric asthma.

\section{LIMITATION OF THE STUDY}

The sample size is small and not focused on the cause of uncontrolled asthma. We need large scale study to understand the factors associated with poorly controlled asthma in the pediatric age group.

\section{CONFLICT OF INTEREST}

No conflict of interest statement.

\section{FINANCIAL DISCLOSURE}

None.

\section{REFERENCES}

1. Masoli M, Fabian D, Holt S, Beasley R; Global Initiative for Asthma (GINA) Program. The global burden of asthma: executive summary of the GINA Dissemination Committee report. Allergy. 2004;59(5):469-478. DOI:10.1111/j.13989995.2004.00526.x

2. World Health Organization. Global surveillance, prevention and control of chronic respiratory diseases: a comprehensive approach. 2007. [Accessed on 10/12/2019]. Available from: http://www. who.int/gard/publications/GARD_Manual/en/

3. Lai CK, Beasley R, Crane J, Foliaki S, Shah J, Weiland S. Global variation in the prevalence and severity of asthma symptoms: Phase three of the international study of asthma and allergies in childhood (ISAAC). Thorax. 2009;64(6):476-483. DOI: 10.1136/thx.2008.106609

4. Pokharel PK, Kabra SK, Kapoor SK, Pandey RM. Risk factors associated with bronchial asthma in school going children of rural Haryana. Indian J Pediatr. 2001;68:103-6. DOI: 10.1007/ BF02722022.

5. Global Initiative for Asthma. Global strategy for Asthma Management and prevention, National Institute of Health, Updated 2012, National Heart, Lung, and Blood institute Revised, 2002. [Accessed on 10/12/2019]. Available from: https:// ginasthma.org/wp-content/uploads /2019/01/2012GINA.pdf

6. Manandhar K, Bajracharya BL, Dhakal S, Shrestha M. Morbidity pattern of children with asthma: a prospective study. KUMJ, 2006, 4(3):324-28 PMID: 18603927

7. Global Initiative for Asthma. Global Strategy for Asthma Management and Prevention 2014. [Accessed on 10/12/2019] Available from: www.ginasthma.com

8. Aggarwal AN, Chaudhry K, Chhabra SK, D'Souza GA, Gupta D, Jindal SK, et al. Prevalence and risk factors for bronchial asthma in Indian adults: A multi-centre study. Indian J Chest Dis Allied Sci. 2006;48: 13-22. PMID: 16482947

9. Olufemi O, Alakija KS, Oluboyo PO. Self reported risk factors of asthma in a Nigerian adult population. Tur Toraks Der. 2009;10:56-62. 
10. Vijayakumar S, Sasikala M, Mohammed TS, Gauthaman K. A perspective study of asthma and its control in Assam. World Acad Sci Eng Technol. 2009;55:134-36. DOI:10.5281/ zenodo.1060966

11. Tse SM, Coull BA, Sordillo JE, Datta S, Gold DR. Gender- and agespecific risk factors for wheeze from birth through adolescence. Pediatr Pulmonol. 2015;50(10):955-962. DOI:10.1002/ ppul.23113

12. Ali A, Sallam MM, Fathy GA, Mohy el din O, Awad SA, Ahmed A. Epidemiological study of the prevalence of bronchial asthma and other atopic diseases among school children in Egypt. Int J Acad Res 2010; 2:209.

13. Lam DSY, Leung SP, So KT. Age of Onset of Asthma Symptoms. HK J Paediatr (new series) 2007;12:11-14. [Accessed on 10/12/2019]. Available from: http://www.hkjpaed.org/pdf /2007; 12;11-14.pdf

14. Singh AM, Moore PE, Gern JE, Lemanske RF Jr, Hartert TV. Bronchiolitis to asthma: a review and call for studies of genevirus interactions in asthma causation. Am J Respir Crit Care Med. 2007;175:108-19. DOI: 10.1164/rccm.200603-435PP. Epub 2006 Oct 19 .

15. Henderson J, Hilliard TN, Sherriff A, Stalker D, Al Shammari N, Thomas HM. Hospitalization for RSV bronchiolitis before 12 months of age and subsequent asthma, atopy and wheeze: a longitudinal birth cohort study. Pediatr Allergy Immunol 2005;16:386-92. DOI: 10.1111/j.1399-3038.2005.00298.x

16. Fjærli HO, Farstad T, Rød G, Ufert GK, Gulbrandsen P, Nakstad B. Acute bronchiolitis in infancy as risk factor for wheezing and reduced pulmonary function by seven years in Akershus County, Norway. BMC Pediatr. 2005;5:31. DOI:10.1186/14712431-5-31

17. Gern JE. The Urban Environment and Childhood Asthma study. J Allergy Clin Immunol. 2010;125(3):545-549. DOI:10.1016/ j.jaci.2010.01.037

18. Guner SN, Gokturk B, Kilic M, Ozkiraz S. The prevalences of allergic diseases in rural and urban areas are similar. Allergologia et Immunopathologia. 2011, 39:140-144. DOI: 10.1016/j.aller.2010.05.004

19. Bisgaard $H, B \emptyset n n e l y k k e ~ K$. Long-term studies of the natural history of asthma in childhood. J. Allergy Clin. Immunol. 2010, 126:187-97. DOI: 10.1016/j.jaci.2010.07.011.

20. Baiardini I, Braido F, Giardini A, Majani G, Cacciola C, Rogaku A, et al. Adherence to treatment: Assessment of an unmet need in asthma. J Investig Allergol Clin Immunol. 2006;16:218-23. PMID: 16889278

21. Horne R. Compliance, adherence, and concordance: Implications for asthma treatment. Chest 2006;130 1 Suppl: 65S-72. DOI: 10.1378/chest.130.1_suppl.65S

22. Jones A, Pill R, Adams S. Qualitative study of views of health professionals and patients on guided self management plans for asthma. BMJ. 2000;321:1507-10. DOI: 10.1136/bmj.321. 7275.1507
23. Melani AS, Bonavia M, Cilenti V, Cinti C, Lodi M, Martucci P, et al. Inhaler mishandling remains common in real life and is associated with reduced disease control. Respir Med. 2011;105:930-8. DOI:https://doi.org/10.1016/ j.rmed. 2011.01.005

24. Boulet LP, Vervloet D, Magar Y, Foster JM. Adherence: The goal to control asthma. Clin Chest Med. 2012;33:405-17. DOI: 10.1016/j.ccm.2012.06.002

25. Global Initiative for Asthma (GINA). 2006 Revision: GINA Report, Global Strategy for Asthma Management and Prevention. Bethesda: NHLBI/WHO; 2006 [assessed on 2019 Nov 16]. Available from: http://www.ginasthma. org/ guidelines-archived-2006-revision.html

26. National Heart, Lung, and Blood Institute; National Asthma Education and Prevention Program. Expert panel report 3: guidelines for the diagnosis and management of asthma. Bethesda: NIH/NHLBI; 2007. [Accessed on 2019 Nov 16]. Available from: http://www.nhlbi.nih.gov/ guidelines/asthma/ asthgdln.pdf

27. Camargos PA, Rodrigues ME, Solé D, Scheinmann P. Asthma and allergic rhinitis as symptoms of the same disease: a paradigm under construction. J Pediatr (Rio J) 2002;78 (Suppl 2):S123-8. DOI:10.1590/S0021-75572002000800003.

28. Bousquet J, Khaltaev N, Cruz AA, Denburg J, Fokkens WJ, Togias A et al. Allergic Rhinitis and its Impact on Asthma (ARIA) 2008 update. Allergy 2008;63 (Suppl 86):8-160. DOI: 10.1111/j. 1398-9995.2007.01620.x.

29. Thomas M, Kocevar VS, Zhang Q, Yin DD, Price D. Asthmarelated health care resource use among asthmatic children with and without concomitant allergic rhinitis. Pediatrics. 2005;115:129-34. DOI: 10.1542/peds.2006-0900LLL

30. Burke W, Fesinmeyer M, Reed K, Hampson L, Carlsten C. Family history as a predictor of asthma. Am. J. Prev. Med.. 24 (2), 2003; 160-69 DOI:10.1016/S0749-3797(02)00589-5

31. Mahdi B, Mahesh PA, Mysore RS, Kumar P, Jayaraj BS, Ramachandra NB. Inheritance patterns, consanguinity \& risk for asthma. Indian J Med Res. 2010 Jul;132:48-55. PMID: 20693589

32. Kalmykova A, Mironova T, Mironov V. Sinus rhythm variability in bronchial asthma. Klinicheskaia meditsina.2007;85 (6): 28-31. PMID: 17682487

33. M Sadhana R. Smita, Wagh, C. Rakesh. A Study of Clinical Profile of Asthma of Pediatric Age Group. Journal of Dental and Medical Sciences.2005; 14 (12): 91-93 DOI: 10.9790/0853141289193

34. Kurz $\mathrm{T}$, Ober $\mathrm{C}$. The role of environmental tobacco smoke in genetic susceptibility to asthma. CurrOpin Allergy Clinlmmunol. 2004; 4: 335-339. DOI: 10.1097/00130832200410000-00002

35. Kinchoku, Mika V, Oliveira, Santana I, Watanabe, Abe L et.al. Factors associated with asthma control in a pediatric reference center. Revista Paulista de Pediatria. 2001; 29(4), 591-98. DOI: 10.1590/S0103-05822011000400019. 
36. Hesselmar B, Aberg N, Aberg B, Eriksson B, Björkstén B. Does early exposure to cat or dog protect against later allergy development? Clin Exp Allergy. 1999 May; 29(5):611-7. DOI: 10.1046/j.1365-2222.1999.00534.x.

37. Hölscher B, Frye C, Wichmann HE, Heinrich. Exposure to pets and allergies in children. J Pediatr Allergy Immunol. 2002 Oct; 13(5): 334-41. DOI:10.1034/j.1399-3038.2002.02063.x

38. Linneberg A, Nielsen NH, Madsen F, Frølund L, Dirksen A, Jørgensen T. Pets in the home and the development of pet allergy in adulthood. The Copenhagen Allergy Study. Allergy. 2003 Jan; 58(1):21-6 DOI:10.1034/j.1398-9995.2003. 23639.x

39. Oberle $D$, von Mutius $E$, von Kries R. Childhood asthma and continuous exposure to cats since the first year of life with cats allowed in the child's bedroom. Allergy. 2003 Oct;58(10):1033-6. DOI: 10.1034/j.1398-9995.2003. 00285.x.
40. Busse WW, Lemanske RF Jr, Gern JE. Role of viral respiratory infections in asthma and asthma exacerbations. Lancet. 2010;376(9743):826-834. DOI: 10.1016/S01406736(10)61380-3

41. Johnston S L, Pattemore P K, Sanderson G. Community study of role of viral infections in exacerbations of asthma in 9-11 year old children. BMJ. 1995;310: 1225-29. DOI: 10.1136/bmj. 310.6989. 1225

42. Nicholson KG, Kent J, Ireland DC. Respiratory viruses and exacerbations of asthma in adults. BMJ. 1993;307:982-6. DOI: 10.1136/bmj.307.6910.982

43. Heymann PW, Carper HT, Murphy DD, Platts-Mills TA, Patrie J, McLaughlin AP, et al. Viral infections in relation to age, atopy, and season of admission among children hospitalized for wheezing. J Allergy Clin Immunol. 2004;114:239-47. DOI: 10.1016/j. jaci.2004.04.006. 